Jurnal Ilmiah Ibnu Sina, 6(1), Maret 2021, 21-28

p-ISSN: 2502-647X; e-ISSN: 2503-1902

\title{
OPTIMASI GEL HAND SANITIZER OLEUM CITRI DENGAN KOMBINASI CARBOPOL, LIDAH BUAYA DAN TEA MENGGUNAKAN SIMPLEX LATTICE DESIGN
}

\author{
Joko Santoso*, Heru Nurcahyo \\ Politeknik Harapan Bersama Tegal \\ *Email: jk23sm@gmail.com \\ Artikel diterima: 02 September 2020; Disetujui: 01 Maret 2021 \\ DOI: https://doi.org/10.36387/jiis.v6i1.569
}

\begin{abstract}
ABSTRAK
Gel handsanitizer tersusun oleh berbagai zat tambahan seperti geling agent, humektan dan netralizing/stabilizing. Bahan ini tentu merupakan bahan dasar yang akan mempengaruhi bentuk dan kualitas sediaan. Carbopol sangat baik bila digunakan sebagai, sehingga dengan kadar rendah dapat memberikan respon viskositas yang signifikan.Sebanyak sebelas formula gel hand sanitizer dengan variasi carbomer, lidah buaya dan TEA diuji sifat fisiknya meliputi organoleptis, uji homogenitas, uji $\mathrm{pH}$, uji daya sebar dan daya lekat. Formula optimum didapatkan dengan metode Simplex Lattice Design yang selanjutnya hasil dianalisis dengan software design expert.

Formula optimum gel hand sanitizer oleum citri yang didapatkan mengandung 0,944 dengan carbomer $0(0,5 \%)$, lidah buaya $0,471(5,239 \%)$ dan TEA $0,529(0,576 \%)$. Pada hasil uji t yang didapat menunjukkan berbeda tidak signifikan antara respon sifat fisik hasil percobaan dan prediksi software.
\end{abstract}

Kata kunci: gel hand sanitizer, carbomer, lidah buaya, TEA, Simplex Lattice Design.

\begin{abstract}
Handsanitizer gel is composed of various additives such as geling agents, humectants and neutralizing / stabilizing agents. This material is certainly a basic ingredient that will affect the shape and quality of the preparation. Carbopol is very good when used, so that low levels can provide a significant viscosity response. Eleven hand sanitizer gel formulas with variations of carbomer, aloe vera and TEA were tested for their physical properties including organoleptic, homogeneity test, pH test, spreadability and adhesion test. The optimum formula is obtained by using the Simplex Lattice Design method, then the results are analyzed using an expert design software.

The optimum formula for oleum citri hand sanitizer gel contains 0.944 with carbomer 0 (0.5\%), aloe vera 0.471 (5.239\%) and TEA $0.529(0.576 \%)$. The t test results obtained showed insignificant differences between the response of the physical properties of the experiment results and the prediction software.
\end{abstract}

Keywords: hand sanitizer gel, carbomer, aloe vera, TEA, Simplex Lattice Desig 
Jurnal Ilmiah Ibnu Sina, 6(1), Maret 2021, 21-28

p-ISSN: 2502-647X; e-ISSN: 2503-1902

\section{PENDAHULUAN}

Penggunaan

antiseptik

merupakan salah satu bentuk perilaku hidup sehat untuk mencegah kuman atau virus berkembang biak atau menular dengan cepat. Kelebihan ini diutarakan menurut US FDA (Foodand Drug Administration) dapat membunuh kuman dalam waktu kurang lebih 30 detik. ( Benjamin, 2010). Susunan bahan antiseptik terutama gel umumnya terbuat dari bahan sintetis yang tidak jarang membuat tidak nyaman dalam pemakaian. Kombinasi bahan alam dalam susunan antiseptik tentu akan mengurangi tingkat iritasi salah satunya lidah buaya sebagai bahan emolient. Hal ini disebabkan karena lidah buaya mengandung lignin atau selulosa yang mampu menembus dan meresap ke dalam kulit serta menahan hilangnya cairan tubuh dari permukaan kulit, sehingga kulit tidak cepat kering dan terjaga kelembabannya (Kathuria dkk.,2011). Carbopol umum digunakan pada pembuatan sediaan gel sebagai bahan pengental atau gelling agent karena memiliki stabilitas yang tinggi. Penambahan bahan netralisasi akan memperbaiki $\mathrm{pH}$ gel yang dihasilkan karena carbopol memiliki $\mathrm{pH}$ yang rendah (Rowe et al.,2009). Maka dari itu perlu adanya bahan yang berfungsi untuk meningkatkan $\mathrm{pH}$ carbopol salah satunya adalah TEA. TEA berfungsi memperpanjang rantai carbopol dengan meningkatkan repulsi agar terbentuk jaringan gel. Selain itu TEA juga membantu stabilitas gel dengan gelling agent karbopol, buffer dan penetral dalam farmasetik topikal (Rowe et al, 2009).

\section{METODE PENELITIAN}

\section{Bahan Baku}

Oleum citri, aquadest, etanol $70 \%$, carbomer, TEA, gliserin, lidah buaya.

Alat

Alat yang digunakan dalam penelitian ini meliputi : gelas ukur $100 \mathrm{~mL}$, beaker glass $250 \mathrm{~mL}$, mortir, stamfer, batang pengaduk, kompor listrik, neraca analitik, stik $\mathrm{pH}$ meter, objek glass, deck glass, alat uji daya lekat, viskometer VT-Rion 04.

\section{Formula Gel Hand Sanitizer}

Formula gel hand sanitizer didapatkan melalui softwer Design Expert menggunakan metode SLD. 
Jurnal Ilmiah Ibnu Sina, 6(1), Maret 2021, 21-28

p-ISSN: 2502-647X; e-ISSN: 2503-1902

Formula yang dihasilkan dari softwer dapat dilihat pada tabel 1 .

\section{Evaluasi Fisik}

a) Uji Organoleptis

Sediaan Gel Hand Sanitizer yang telah dibuat dilakukan pengamatan fisik meliputi bentuk, bau dan warna sediaan.

b) $\mathrm{Uji} \mathrm{pH}$

Pengukuran $\mathrm{pH}$ menggunakan indikator $\mathrm{pH}(\mathrm{pH}$ stick) dengan cara memasukkannya ke dalam sediaan gel hand sanitizer kemudian diamati (Santoso,J dan Riyanta, AB, 2018).

c) Uji Homogenitas

Homogenitas dilakukan untuk mengamati dan memastikan bahwa sediaan krim sudah tercampur secara homogen. Mengambil sediaan gel kemudian mengoleskan ke kaca preparat dan diamati apakah ada partikel kasar dalam krim. Jika masih terdapat pertikel kasar maka dapat dikatakan gel tersebut belum tercampur homogeny (Herowati, R dkk. 2018).

d) Uji Daya Sebar
Pengukuran daya sebar sediaan gel dilakukan setelah 48 jam pembuatan. Daya sebar diukur dengan cara menimbang gel sebanyak 1 gram kemudian meletakkan di tengah lempeng bulat berskala. Selanjutnya meletakan pemberat sehingga berat kaca bulat dan pemberat 125 gram, didiamkan selama 1 menit, kemudian dicatat diameter sebarnya (Garg et al., 2002).

e) Uji Viskositas

Uji viskositas dilakukan setelah penyimpanan selama 48 jam setelah pembuatan krim. Pengukuran viskositas krim menggunakan alat Rheon 1 viscotester VT-04. Meletakan krim di atas cone berdiameter $5 \mathrm{~cm}$ dan dihimpitkan dengan plate hingga cukup tipis namun kondisi dijaga agar cone dan plate tidak bergesekan. Parameter pengukuran diatur sama sehingga semua formula mengalami perlakuan yang sama (Yovita, 2016). 
Jurnal Ilmiah Ibnu Sina, 6(1), Maret 2021, 21-28

p-ISSN: 2502-647X; e-ISSN: 2503-1902

Tabel 1. Formula Gel Hand Sanitizer

\begin{tabular}{ccccccccccccc}
\hline Bahan & \multicolumn{10}{c}{ Formula (\%) } \\
\cline { 2 - 12 } & 1 & 2 & 3 & 4 & 5 & 6 & 7 & 8 & 9 & 10 & 11 \\
\hline Oleum & 5 & 5 & 5 & 5 & 5 & 5 & 5 & 5 & 5 & 5 & 5 \\
$\quad$ Citri & & & & & & & & & & & \\
Carbomer & 0,75 & 1,5 & 0,99 & 0,5 & 0,75 & 0,5 & 2 & 1,25 & 2 & 1,25 & 0,5 \\
$\quad$ Lidah & 7,00 & 2,53 & 3,97 & 1 & 2,50 & 5,5 & 1 & 5,5 & 1 & 1 & 10 \\
Buaya & & & & & & & & & & & \\
$\quad$ TEA & 0,25 & 0,253 & 0,397 & 1 & 0,7 & 0,55 & 0,1 & 0,1 & 0,1 & 0,5 & 0,55 \\
Alkohol & 70 & 70 & 70 & 70 & 70 & 70 & 70 & 70 & 70 & 70 & 70 \\
$\quad$ 70\% & & & & & & & & & & & \\
Aquadest & 17 & 17 & 17 & 17 & 17 & 17 & 17 & 17 & 17 & 17 & 17 \\
\hline
\end{tabular}

\section{HASIL DAN PEMBAHASAN}

\section{Pembuatan Hand Sanitizer}

Pembuatan handsanitier diawali dengan menaburkan carbomer di atas air sebanyak 20 kali bagian dari karbomer lalu didiamkan 30 menit hingga terdispersi dan mengembang. Proses ini membuat ikatan silang pada polimer sehingga molekul pelarut terjebak didalamnya, kemudian terjadi immobilisasi molekul pelarut dan terbentuk struktur yang kaku dan tegar yang tahan terhadap gaya maupun tekanan tertentu. Aduk carbomer sambil tambahkan sedikit demi sedikit sampai seluruh ikatan terurai, kemudian tambahkan TEA untuk membentuk massa gel. Larutan lidah buaya kemudian ditambahkan ke masa gel sambil aduk konstan sambil tambahkan sisa air sampai homogen.

\section{Evaluasi Fisik}

1. Organoleptis

Sifat fisik ini dilakukan bertujuan mengetahui bentuk bau, warna dan rasa dari sediaan. Berdasarkan hasil uji organoleptis didapatkan, seluruh formula bentuk sediaan semisolid gel, jernih, berwarna kekuningan dan berasa dingin ketika digunakan.

2. Uji Homogenitas

Tabel 2. Hasil Uji Sifat Fisik

\begin{tabular}{cccc}
\hline & \multicolumn{3}{c}{ Uji Sifat Fisik } \\
\cline { 2 - 4 } Formula & PH & $\begin{array}{c}\text { Diameter } \\
(\mathrm{cm})\end{array}$ & $\begin{array}{c}\text { Viskositas } \\
(\mathrm{cP})\end{array}$ \\
\hline $\mathbf{1}$ & 7 & 3,9 & 375,7 \\
$\mathbf{2}$ & 6 & 3,7 & 617,87 \\
$\mathbf{3}$ & 7 & 3,8 & 486,88 \\
$\mathbf{4}$ & 7 & 4,2 & 465,71 \\
$\mathbf{5}$ & 7 & 4,5 & 585,66 \\
$\mathbf{6}$ & 7 & 5,6 & 347,06 \\
$\mathbf{7}$ & 6 & 3,1 & 1030,2 \\
$\mathbf{8}$ & 6 & 3,4 & 406,8 \\
$\mathbf{9}$ & 6 & 3,5 & 980,5 \\
$\mathbf{1 0}$ & 7 & 3,4 & 499,08 \\
$\mathbf{1 1}$ & 7 & 4,8 & 356,8 \\
\hline
\end{tabular}


Jurnal Ilmiah Ibnu Sina, 6(1), Maret 2021, 21-28

p-ISSN: 2502-647X; e-ISSN: 2503-1902

Pada uji homogenitas pada sediaan gel hand sanitier didapat hasil homogen pada tiap formula. Hasil dikatakan homogen jika sediaan tidak memiliki butiran kasar (Santoso, J. Herowai,R. Murrukmihadi, M . 2018).

Hasil uji pH, daya lekat dan daya sebar dapat dilihat pada tabel 2 .

3. $\mathrm{Uji} \mathrm{pH}$

Berdasarkan tabel 2 hasil uji $\mathrm{pH}$ berada pada range $\mathrm{pH}$ kulit yaitu 4-6,5 (Santoso, J dan Riyanta, AB, 2018). Uji pH bertujuan untuk menyesuaikan ph sediaan dengan $\mathrm{pH}$ kulit, sehingga ketika saat digunakan kulit tidak mengalami iritasi.

4. Uji daya sebar

Daya sebar yang ditampilkan pada tabel 2 menujukan bahwa formula 6 memiliki daya sebar tertinggi sebesar 5,6 $\mathrm{cm}$ dengan variasi carbomer $0,5 \%$, lidah buaya $5,5 \%$, TEA $0,55 \%$. Selanjutnya dilakukan pengolahan statistik dengan Simplex Lattice Design yang bertujuan untuk mengetahui pengaruh ketiga faktor terhadap daya sebar gel. Persamaan yang diperoleh dari program merupakan sebuah persamaan, yang ditunjukkan pada persamaan berikut.

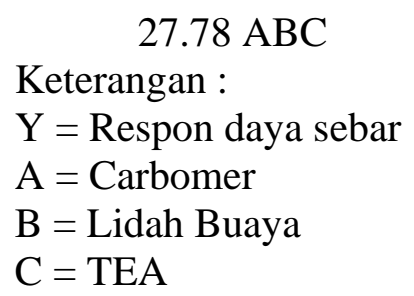

Keterangan :

$\mathrm{Y}=$ Respon daya sebar

$\mathrm{A}=$ Carbomer

$\mathrm{B}=$ Lidah Buaya

$\mathrm{C}=$ TEA

$\begin{array}{rrr}\text { Persamaan } & \text { yang } & \text { didapat } \\ \text { melalui Simplex } & \text { Lattice } & \text { Design }\end{array}$ merupakan persamaan special cubic dimana carbomer, lidah buaya dan TEA memberikan respon positif terhadap daya sebar. Iteraksi lidah buaya dan TEA memberikan respon yang paling besar terhadap nilai daya sebar. Lidah memiliki kemampuan menurunkan vikositas sediaan gel. Berdasarkan grafik pada software Design Expert terlihat bahwa semakin tinggi konsentrasi lidah buaya maka akan semakin kecil nilai viskositas, sehingga akan ada peningkatan yang besar terhadap nilai daya sebar sediaan.
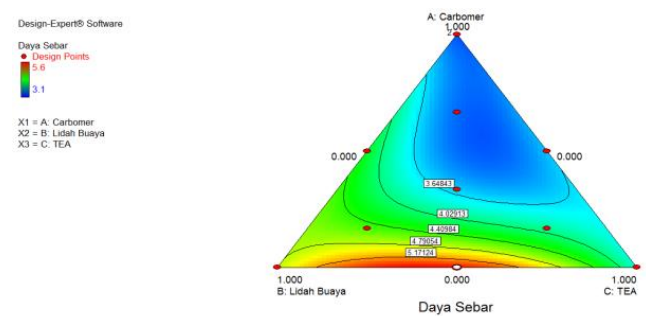

Gambar 1. Grafik daya sebar gel hand sanitizer 
Jurnal Ilmiah Ibnu Sina, 6(1), Maret 2021, 21-28

p-ISSN: 2502-647X; e-ISSN: 2503-1902

\section{Uji Viskositas}

Viskositas yang ditampilkan pada tabel 2 menujukan bahwa formula 7 memiliki viskositas tertinggi sebesar 1030,2 cP dengan variasi carbomer $2 \%$, lidah buaya $1 \%$ dan TEA $0,1 \%$. Selanjutnya dilakukan pengolahan statistik dengan Simplex Lattice Design yang bertujuan untuk mengetahui pengaruh ketiga faktor terhadap viskositas gel. Persamaan yang diperoleh dari program merupakan sebuah persamaan, yang ditunjukkan pada persamaan berikut. $\mathrm{Y}=893.59 \mathrm{~A}+255.33 \mathrm{~B}+428.68$

Keterangan :

$\mathrm{Y}=$ Respon daya sebar

$\mathrm{A}=$ Carbomer

$\mathrm{B}=$ Lidah Buaya

$\mathrm{C}=$ TEA

Persamaan yang didapat melalui Simplex Lattice Design merupakan persamaan linier dimana carbomer, lidah buaya dan TEA memberikan respon positif terhadap viskositas. Carbomer memberikan respon yang paling besar terhadap nilai viskositas. Carbomer memiliki kemampuan meningkatkan vikositas sediaan gel. Berdasarkan grafik pada software Design Expert terlihat bahwa semakin tinggi konsentrasi carbomer maka akan semakin tinggi nilai viskositas, sehingga akan ada penurunan terhadap nilai daya sebar sediaan.
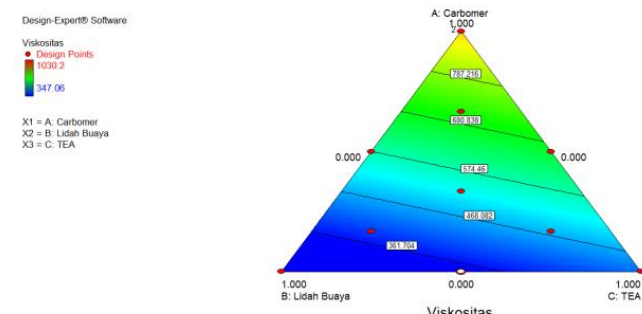

Gambar 2. Grafik viskositas gel hand sanitizer

\section{Penentuan formula optimum}

Carbomer, Lidah buaya dan TEA merupakan faktor yang diteliti sehingga target respon dipilih in range. Derajat kepentingan respon untuk daya sebar adalah (+++++) dengan target respon maximize karena daya sebar merupan faktor yang penting dalam sediaan gel terutama dalam hal distribusi zat aktif dalam penggunaannya. Derajat kepentingan respon untuk viskositas adalah $(+++)$ dengan target respon in range sehingga penetapan formula memberikan nilai viskositas akan berada pada nilai minimize dan maximize yang diharapkan.

Setelah semua respon dimasukan dalam software maka akan menghasilkan solusi variasi bahan dan prediksi nilai respon yang 
Jurnal Ilmiah Ibnu Sina, 6(1), Maret 2021, 21-28

p-ISSN: 2502-647X; e-ISSN: 2503-1902

dikehendaki. Dari hasil analisis tersebut dihasilkan superimprosed dari contour plot respon daya sebar dan viskositas gel hand sanitizer .

Tabel 3. Prediksi formula dan sifat fisik optimum gel hand sanitizer

\begin{tabular}{cc}
\hline NO & $\mathbf{1}$ \\
\hline Carbomer & 0,5 \\
Lidah buaya & 5,24 \\
TEA & 0,58 \\
Viscositas (cP) & 347,06 \\
Daya sebar & \\
(cm) & 5,460 \\
Desirability & 0,944 \\
\hline
\end{tabular}

Berdasarkan prediksi tersebut dihasilkan formula dengan nilai desirability sebesar 0,944 dengan carbomer $0(0,5 \%)$, lidah buaya 0,471 $(5,239 \%)$ dan TEA $0,529(0,576 \%)$ seperti yang ditunjukkan pada gambar 4.3. Daerah tersebut memberikan satu prediksi formula gel optimum dengan nilai desirability sebesar 0.944 . Nilai desirability yang semakin mendekati 1 menunjukkan formula yang diharapkan, sebaliknya jika nilai desirability semakin mendekati 0 menunjukkan formula yang tidak diharapkan (Lawler et al., 2007).

\section{Verifikasi Formula Optimum}

Formula optimum yang sudah diprediksi oleh software Design Expert diuji kebenarannya dengan

membuat kembali gel hand sanitizer dengan metode pembuatan yang sama kemudian dilakukan uji fisik berupa viskositas dan daya sebar. Hasil verifikasi kemudian dianalisis secara statistik untuk membandingkan antara software dan hasil praktek ada perbedaan atau tidak.

Tabel 4. Verifikasi formula optimum prediksi terhadap percobaan

\begin{tabular}{lcc}
\hline Respon & $\begin{array}{c}\text { Viskositas } \\
(\mathbf{C p})\end{array}$ & $\begin{array}{c}\text { Daya } \\
\text { Sebar } \\
(\mathbf{c m})\end{array}$ \\
\hline $\begin{array}{l}\text { Nilai } \\
\text { prediksi }\end{array}$ & 347,06 & 5,460 \\
Nilai & $346,67 \pm 16$ & $5,713 \pm 0,48$ \\
percobaan &, 623 & 4 \\
Signifikansi & 0,969 & 0,363 \\
Kesimpulan & Berbeda & Berbeda \\
& tidak & tidak \\
& signifikan & signifikan \\
\hline
\end{tabular}

Data hasil anlisis secara statistik diperoleh nilai signifikansi sebesar $>0,05$ pada semua respon, hal ini menandakan bahwa nilai uji fisik pada formula optimum gel hand sanitizer terhadap nilai prediksi software adalah berbeda tidak signifikan, maka nilai prediksi software benar dan dapat dipercaya.

\section{KESIMPULAN}

1. Adanya pengaruh kombinasi carbopol, lidah buaya dan TEA 
Jurnal Ilmiah Ibnu Sina, 6(1), Maret 2021, 21-28

p-ISSN: 2502-647X; e-ISSN: 2503-1902

terhadap sifat fisik gel

handsanitizer oleum citri.

2. Formula optimum yang didapatkan menggunakan metode Simplex

Lattice Design yaitu carbopol $0,5 \%$, lidah buaya $5,24 \%$ dan TEA $0,58 \%$

\section{DAFTAR PUSTAKA}

Benjamin, D.T. (2010). Introduction to hand sanitizer. http://www.antimicrobialtestlab oratories.com/information_abou t_hand_a nitizer.html. Diakses April 2020

Garg, A., D. Aggarwal, S. Garg, and A. K.Sigla. 2002. Spreading of Semisolid Formulation: An Update. Pharmaceutical Tecnology. September: 84-102.

Herowati,R., Indrayati, A.,Damayantie, Wury., Santoso, Joko., 2018. Antibacterial Activity of Topical Polyherbal Formulation on Pseudomonas aeruginosa. Advanced Science Letters, Volume 24, Number 1, pp. 121-124(4)

N Kathuria, N Gupta, Manisha, R Prasad, Nikita. Biologic Effects Of Aloe Vera Gel. The Internet Journal of Microbiology. 2010 Volume 9 Number 2.

Lawler, J. S, National Cooperative Highway Research Program, National Research Council, Transportation Research Board, dan United States Federal Highway

Administration.,(2007),
Guidelines for Concrete Mixtures Containing Supplementary Cementitious Materials to Enhance Durability of Bridge Decks. Washington DC : National Cooperative Highway Research Program.

Rowe, Raymond C., dkk 2009, Handbook of pharmaceutical Excipient, Sixth Edition. London; Pharmaceutical Press.

Santoso, J. Herowai, R. Murrukmihadi,M . 2018. Optimasi Formula Ekstrak Poliherbal Sebagai Antibakteri Dengan Kombinasi Gliserin, Sorbitol dan Propilenglikol Sebagai Humektan. Surakarta. Universitas Setia Budi

Santoso, J dan Riyanta, AB. 2019. Aktivitas Antibakteri Sediaan Foot Sanitizer Spray YangMengandung Ekstrak Biji Kopi Dan Jahe. Journal Parapemikir. Volume 8, No 1, 2019

Yovita, Vinsensia SR. 2016. Optimasi Parafin Cair Sebagai Emolien dan Gliserol Sebagai Humektan dalam Sediaan Krim Ekstrak Kulit Buah Manggis (Garcinia mangostana L.) Serta Uji Aktivitas Antioksidan. Yogyakarta. Universitas Sanata Dharma. 